Archiv für die gesamte Virusforschung 35, 183-193 (1971)

(C) by Springer-Verlag 1971

\title{
Zika Virus Infection of the Central Nervous System of Mice
}

\author{
By \\ T. M. BeLl, E. J. Field, and H. K. Narang \\ Medical Research Council, Demyelinating Diseases Unit, Newcastle General Hospital, \\ Neweastle upon Tyne, England \\ With 8 Figures \\ Received February 10, 1971

\begin{abstract}
Summary
Intracerebral inoculation of newborn and 5-week-old mice with Zika virus resulted in an early and marked enlargement of astroglial cells with patchy destruction of the pyriform cells of Ammon's horn. Replication of the virus was demonstrated in both neurones and astroglial cells. New virions appeared to be formed within networks of endoplasmic reticulum. The similarity of these ultrastructural observations to those obtained from in vivo studies of other group B arboviruses is contrasted with the widely differing findings from in vitro studies.
\end{abstract}

\section{Introduction}

Zika virus is a group B arbovirus prevalent in central Africa. Originally isolated from a sentinel rhesus monkey in the Zika forest, near Entebbe, Uganda (1), it has since been recovered frequently from mosquitoes of the Aedes (Stegomyia) africanus (Theobald) species in the same area $(2,3,4)$. All isolates have been readily adapted to intracerebral passage, initially in 5- to 6-week-old adult mice (5), but latterly in 1-to 5-day-old suckling mice (2). Pathological changes are confined to the central nervous system in older animals, but myocarditis and skeletal myositis are also found in the young animals (2). In this study pathological changes in brain are correlated with growth of the virus as demonstrated in the electron microscope and the general pattern of replication of the group B arboviruses is discussed.

\section{Materials and Methods}

\subsection{Virus}

One ampoule of the MP 1751 strain of Zika virus was kindly supplied by the Director, East African Virus Research Institute, Entebbe, Uganda. This strain was isolated from a pool of $50 \mathrm{~A}$. (S.) africanus collected at the Zika forest on 1.11.1962 and passaged intracerebrally once in baby mice before lyophilization. The freeze-dried powder was rehydrated with sterile double-distilled water and diluted 1:10 in Eagle's BME (Wellcome TC 48). 


\subsection{Inoculation of Mice}

One-day-old Webster Swiss (WS) white mice were inoculated intracerebrally with $0.03 \mathrm{ml}$ of the reconstituted virus and observed daily. On the seventh post-inoculation day all animals fell sick, and the brains were harvested. A $10 \%$ suspension of brain was prepared and used as a pool to inoculate further one-day-old WS mice. These animals fell sick on day six and were either perfused with a formal, methanol, acetic acid fixative, or the brains were fixed in formal ammonium bromide or glutaraldehyde. Five-week-old mice were also inoculated intracerebrally and approximately $20 \%$ became obviously sick between days 14 and 20 . The brains were fixed in formal ammonium bromide. Histological and electron microscopical examinations were carried out as previously described (6).

\subsection{Confirmation of Identity of Virus}

The mouse brain pool of Zika virus was titrated in stationary tube cultures of secondary rhesus monkey kidney (RMK) cells and the $\mathrm{TCD}_{50}$ calculated. Reference antiserum prepared against the prototype strain of Zika virus was obtained from the Director, E.A.V.R.I., Entebbe. A neutralization test using serial 2-fold dilutions of this serum against $100 \mathrm{TCD}_{50}$ of the MP 1751 strain of Zika virus was set up in monolayer cultures of RMK cells.

\section{Results}

\subsection{Histopathology}

The most striking changes were found in Ammon's horn, where there were localized segments of necrosis in the band of pyriform cells (Fig. 1 a, b, c, d). Much

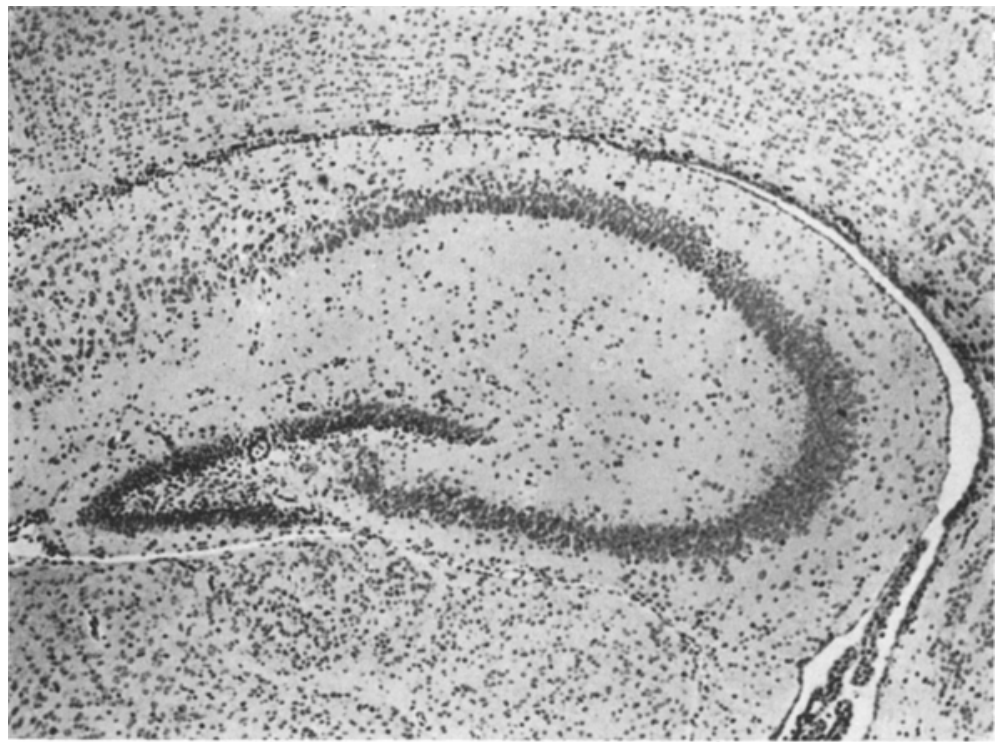

Fig. 1 a. Normal Ammon's horn of mouse $\mathrm{i}$-days-old. Note regular arrangement of pyriform cells. H. L. $\times 56$

scattered hyperchromatic nuclear debris was present and the tissue presented a moth-eaten appearance. Moderate perivascular cuffing was occasionally seen. Astrocyte hypertrophy was prominent (Fig. 2a, b). The relatively plump cells of the new born animal were enlarged and presented more branched processes. Microglial cells were not prominent. In the 5-week-old mouse (where the disease 
took about 14 days to develop) astroglial changes were again remarkable (Fig. 3). The normal animal at eight weeks has wispy and poorly stainable astroglial cells in the Cajal preparation. Astroglial changes in the baby mouse were limited to Ammon's horn but in the 5-week-old animals infected astroglia was prominent throughout the cortex.

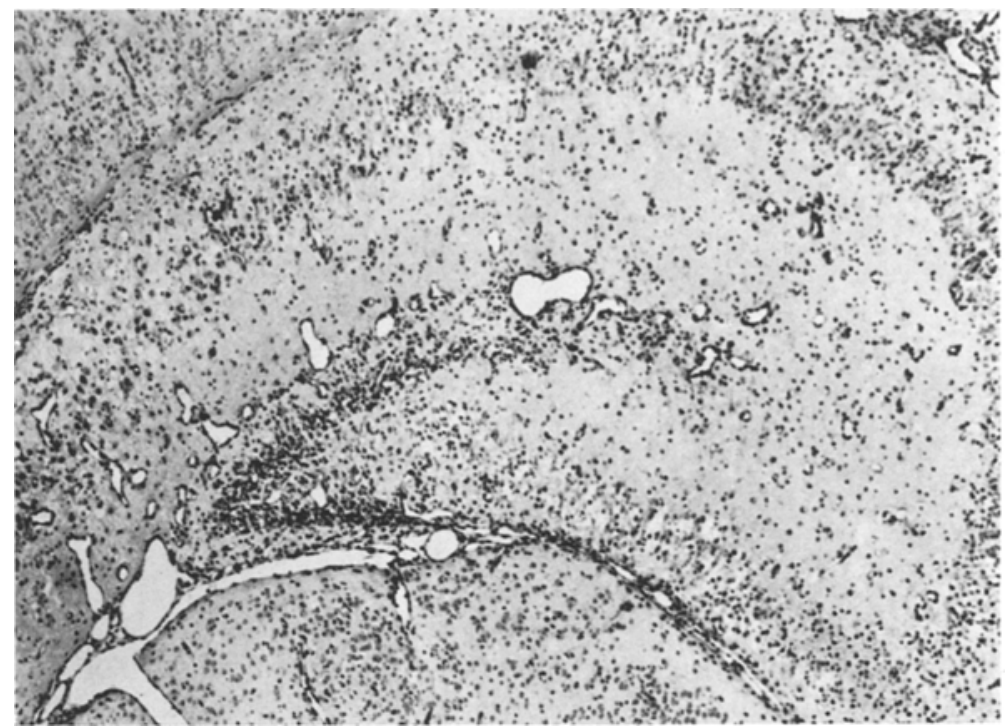

Fig. 1 b. Ammon's horn of Zika infected monse 7-days-old. Note disorganization of pyriform cell layer and dilatation of ressels in white matter with only very slight perivascular cuffing. H.E. $x$. 6

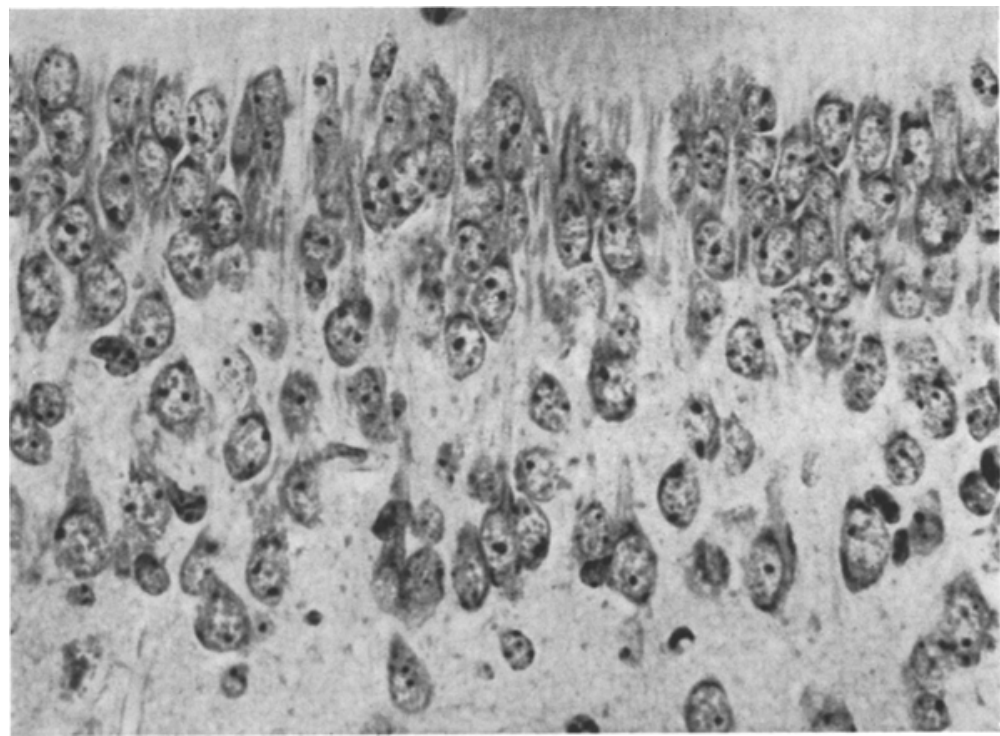

Fig. 1c. Normal pyriform cells: 7 -days-old mouse. H.F. $\times 560$

In the cortex of the baby mouse there were many nerve cells with "empty" vesicular nuclei and some interstitially scattered nuclear chromatin particles (Fig. 4a, b). Perivascular cuffing was not seen. 


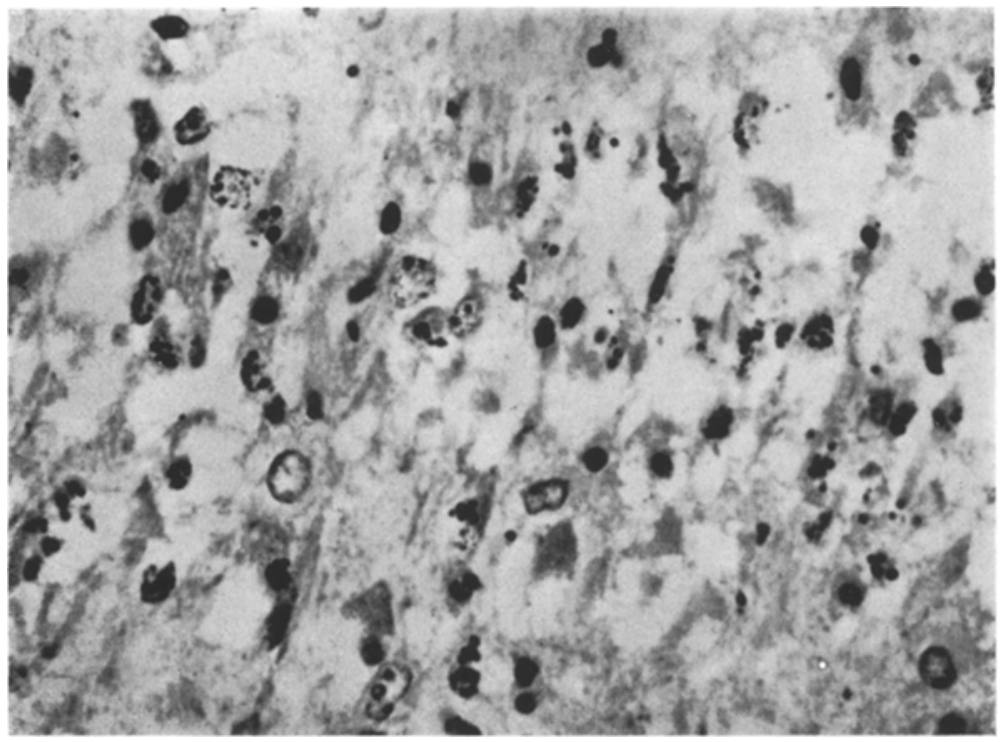

Fig. 1d. Same area in 7-days old Zika infected mouse. H.E. $\times 560$

\subsection{Electron Microscopy}

Examination of the cortex and Ammon's horn of 7-day-old mice injected intracerebrally when 1-day-old with the MP 1751 strain of Zika virus revealed

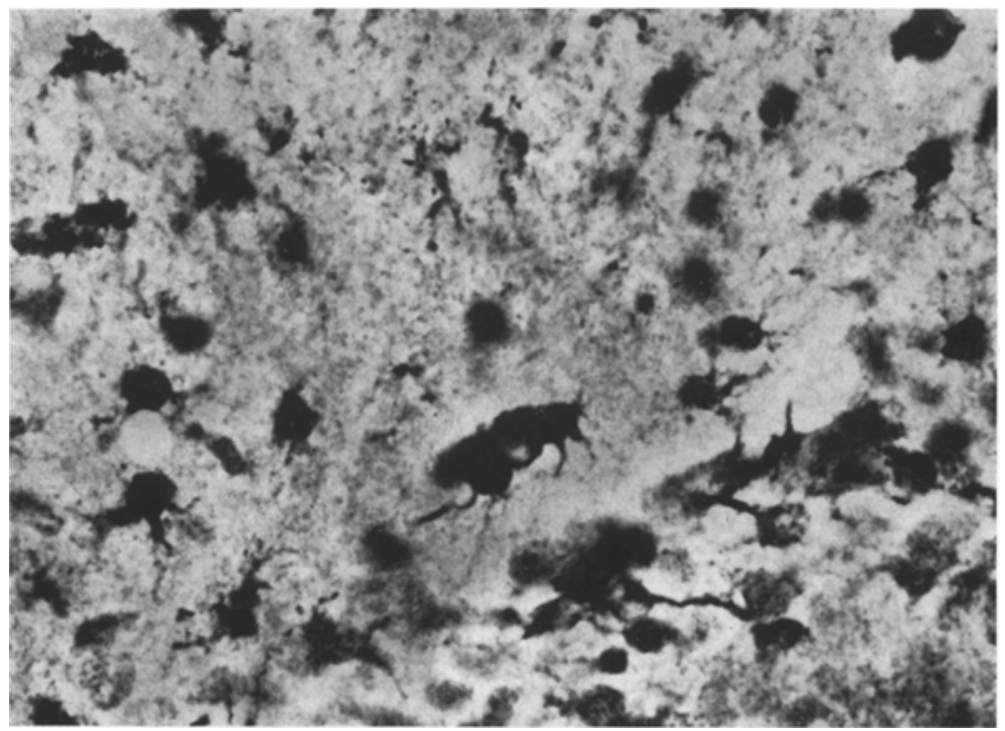

Fig. 2a. Astrocytes in Ammon's horn of normal 7-days-old mouse. Note plump cells with relatively simple process

numerous cells containing intracytoplasmic inclusions or "virus factories" (Figs. 5,6 and 7). Both glial cells and neurons were affected and more than one "factory" could sometimes be seen in a single neurone process (Fig. 5). In those cell profiles 


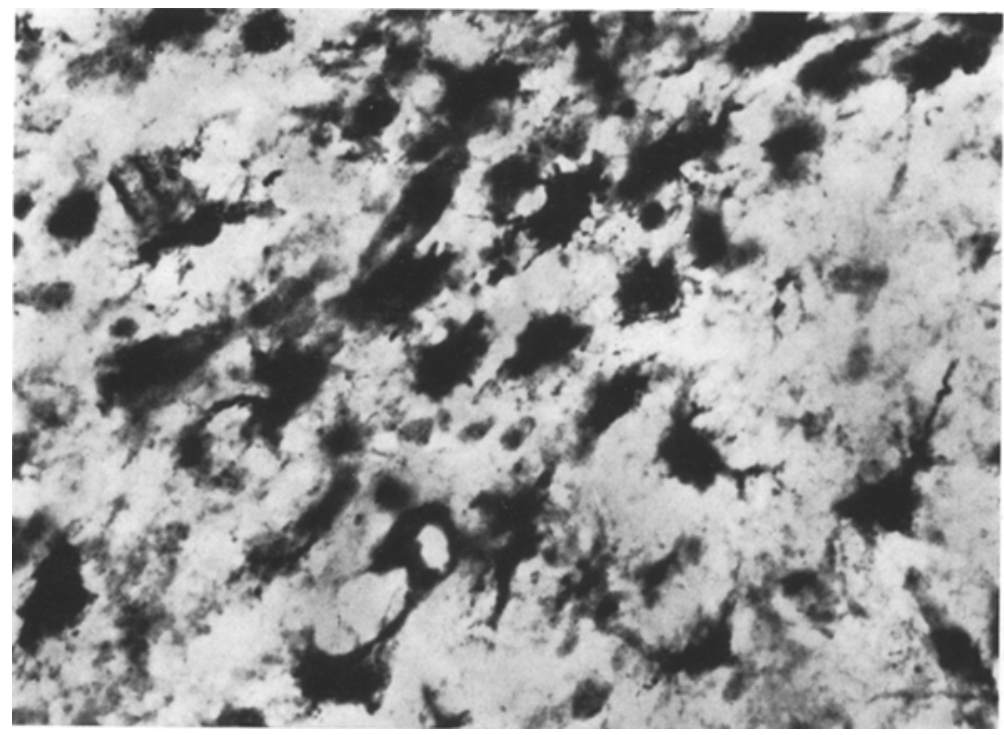

Fig. 2 b. Astrocytes in Ammon's horn of 7-day-old mouse with Zika infection. Note increased number of astrocy tes with plump bodies and large numbers of processes. Cajal gold chloride impregnation $\times 560$

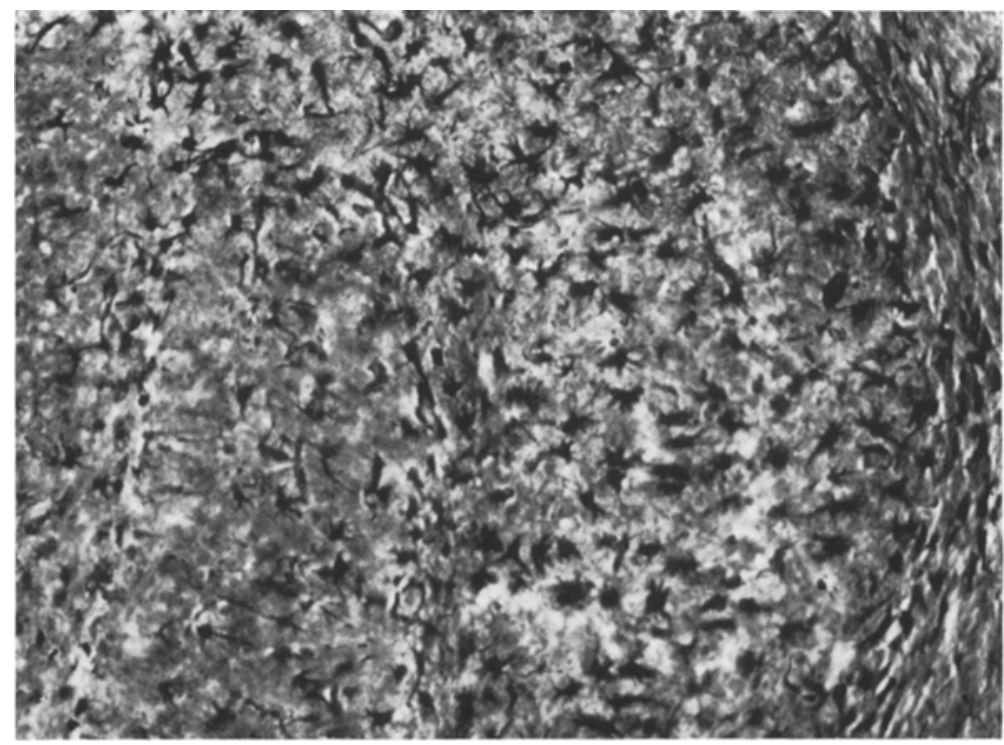

Fig. 3. Ammon's horn of 50-day-old mouse with Zika infection. Note large numbers of well impregnated astrocytes. Cajal gold chloride impregnation $\times 140$

which included a section of the nucleus, the "virus factories" were usually found in close proximity to it (Fig. 6).

The "factories" were composed of a network of endoplasmic reticulum and large numbers of distended endoplasmic cisternae (Fig. 8). These enclosed numerous vesicular bodies, 74 to $78 \mathrm{~m} \mu$ in diameter, within which there was a fine reticular network. Dense-cored particles, with the typical appearance of 
group B arboviruses, were found throughout the "factories". These particles had an overall diameter of 40 to $43 \mathrm{~m} \mu$, the central core being 28 to $30 \mathrm{mu}$. The virions were frequently found in short chains within tubular elements of endoplasmic reticulum which appeared to be in continuity with the distended cisternae (Fig. 8).

The cytoplasm of infected cells appeared normal in areas removed from the "virus factories" and large numbers of mitochondria were present in these cells, many adjacent to the "factories".

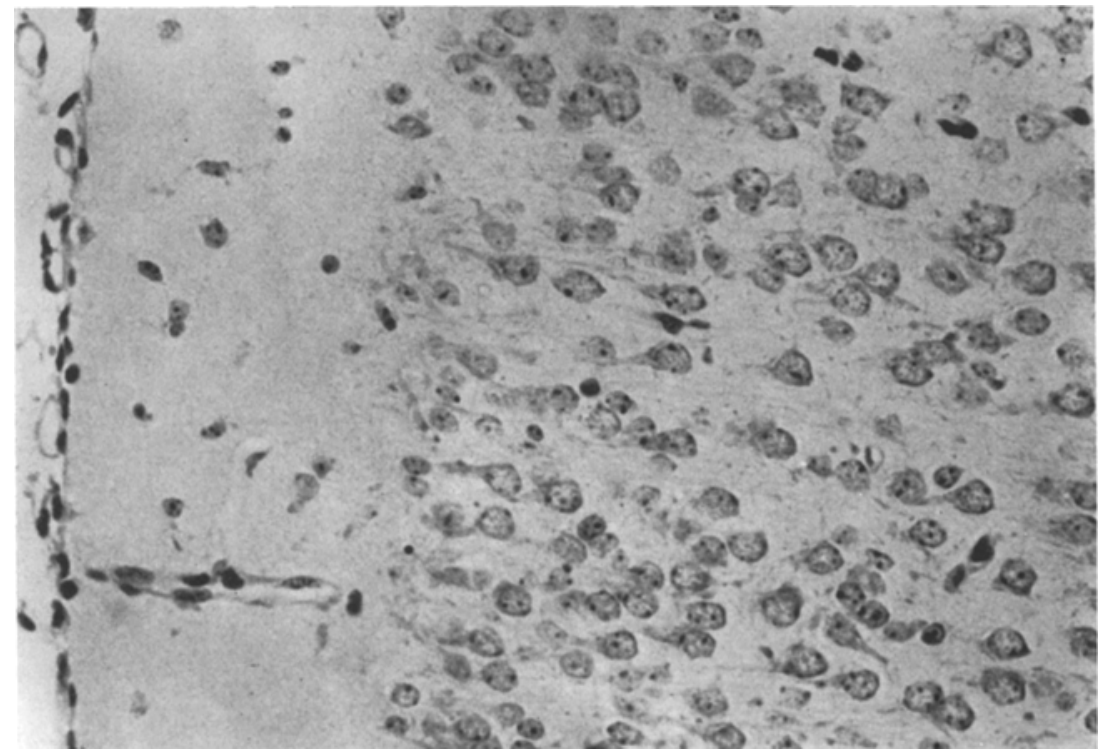

Fig. 4 a. Cerebral cortex of 7-day-old normal mouse. Note well stained nuclei

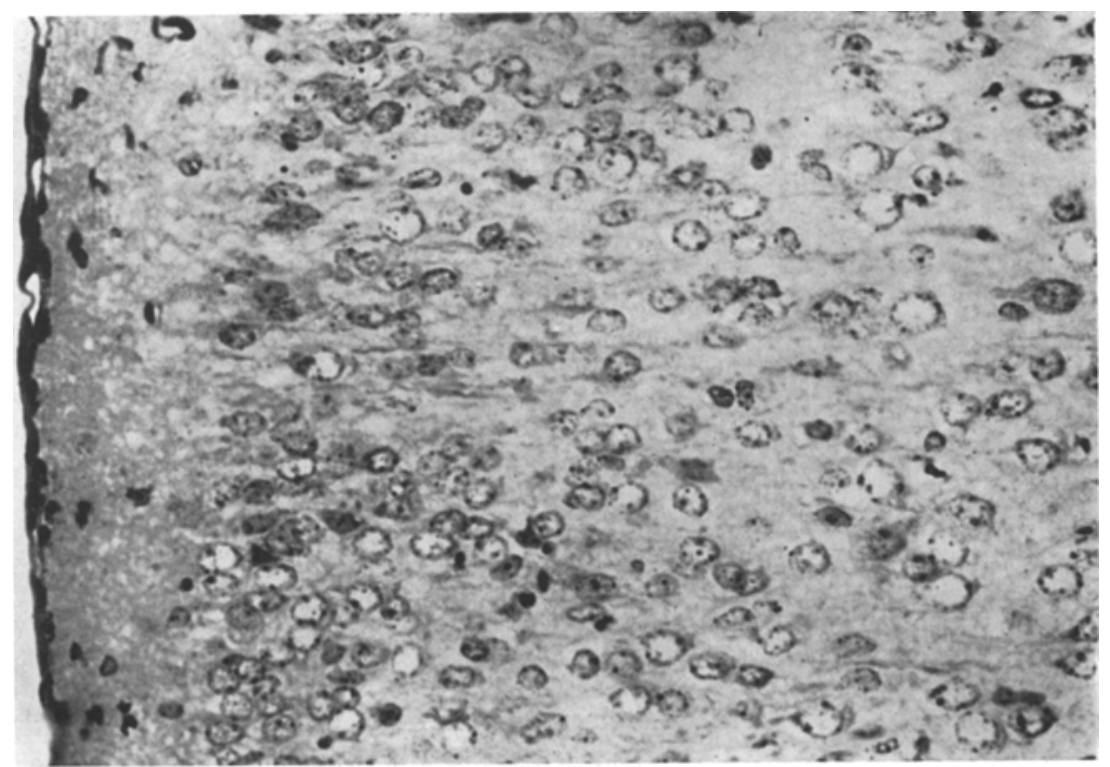

Fig. 4 b. Same area in 7 -day-old Zika infected mouse. Note margination of chromatin in neurones and nuclear debris. There is no perivascular cuffing. H.E. $\times 350$ 


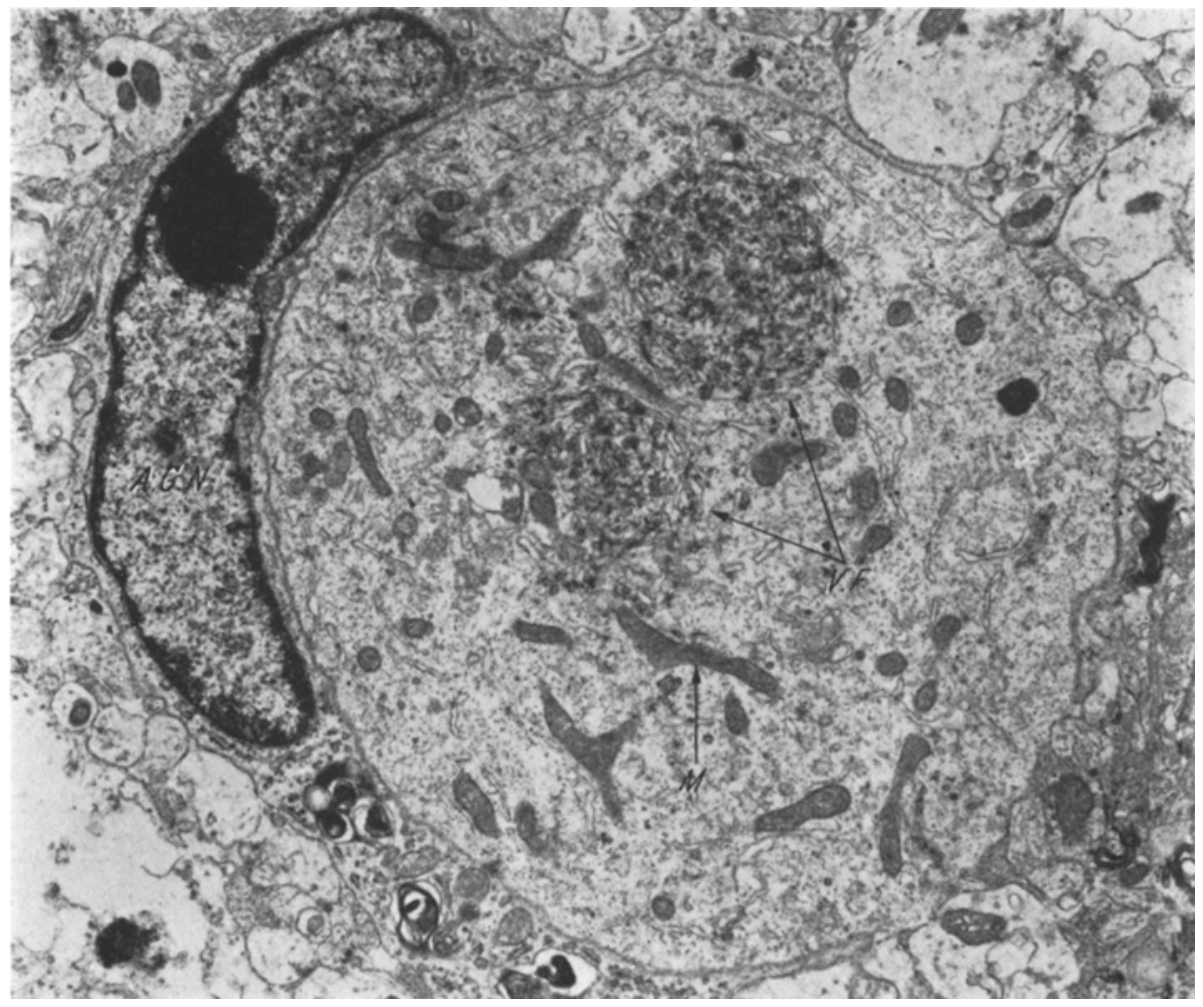

Fig. 5. Ammon's horn of 7-day-old mouse infected with Zika virus. Profile of dendrite embraced by an astroglial cell (AGN). Two virus factories (VF) are visible. Mitochondria are dark (M) $\times 9,800$

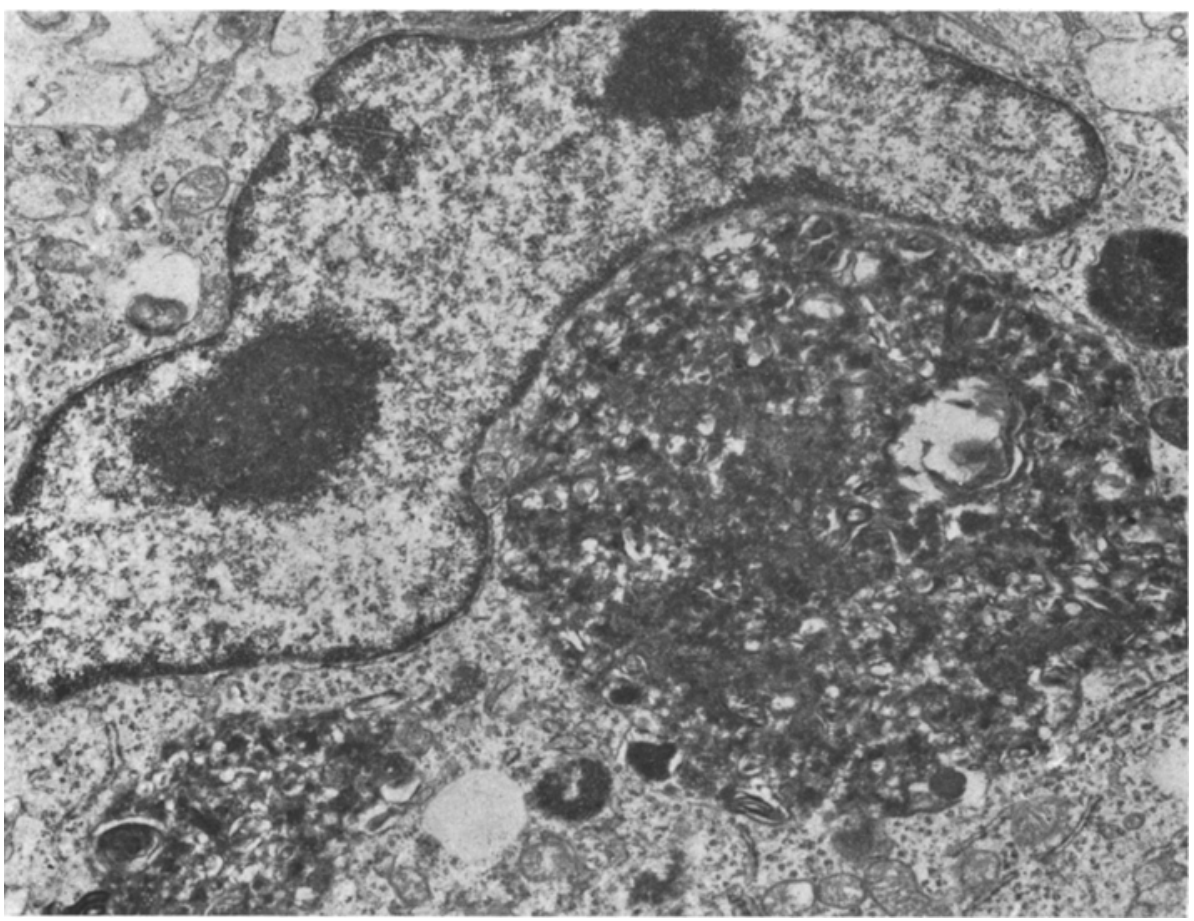

Fig. 6. Virus factory (more advanced stage than fig. 5) in cytoplasm of astroglial cell. $\times 11,500$ 


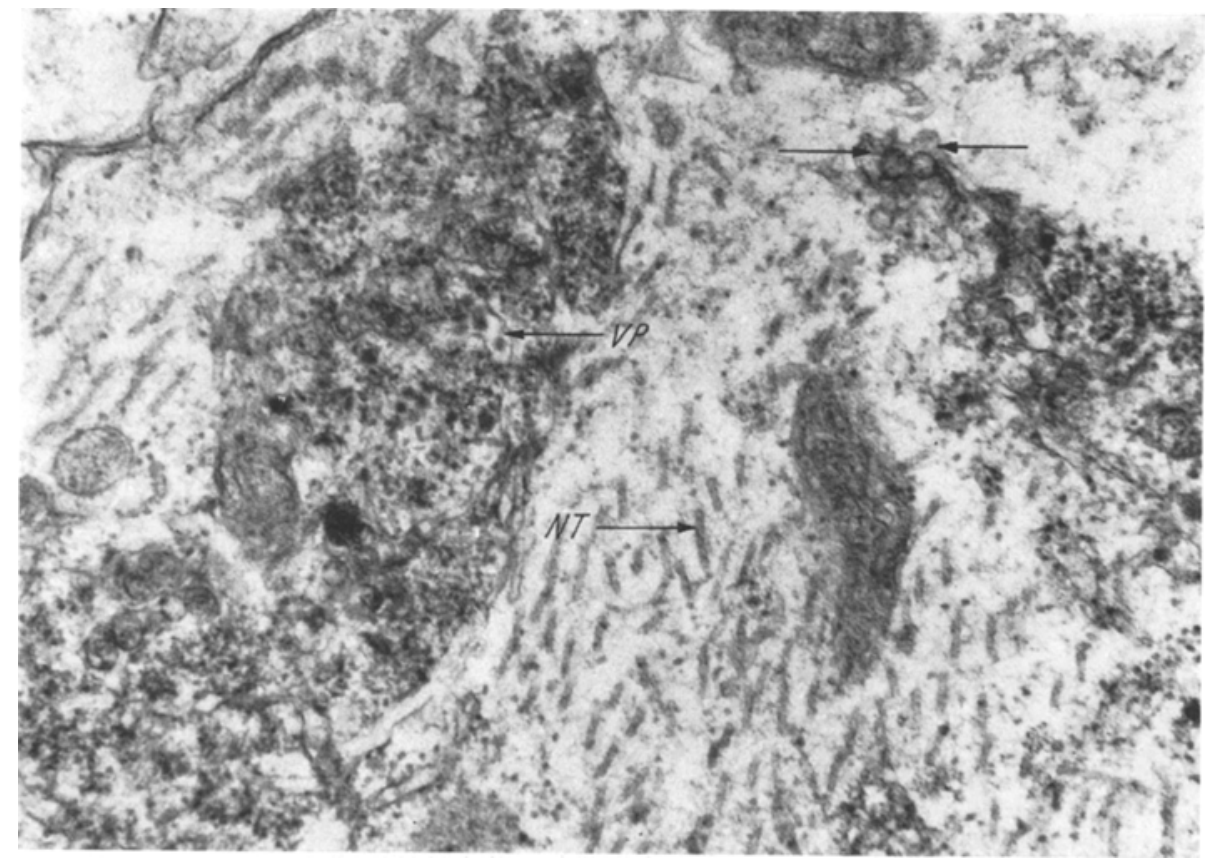

Fig. 7. Ammon's horn 7-day-old monse infected with Zika. Virus factory containing individual virion (VP) present in cytoplasm of pyriform nerve cell. Neurotubules are prominent (NT). Endoplasmic reticulum contains vesicles (arrows) $\times 38,000$

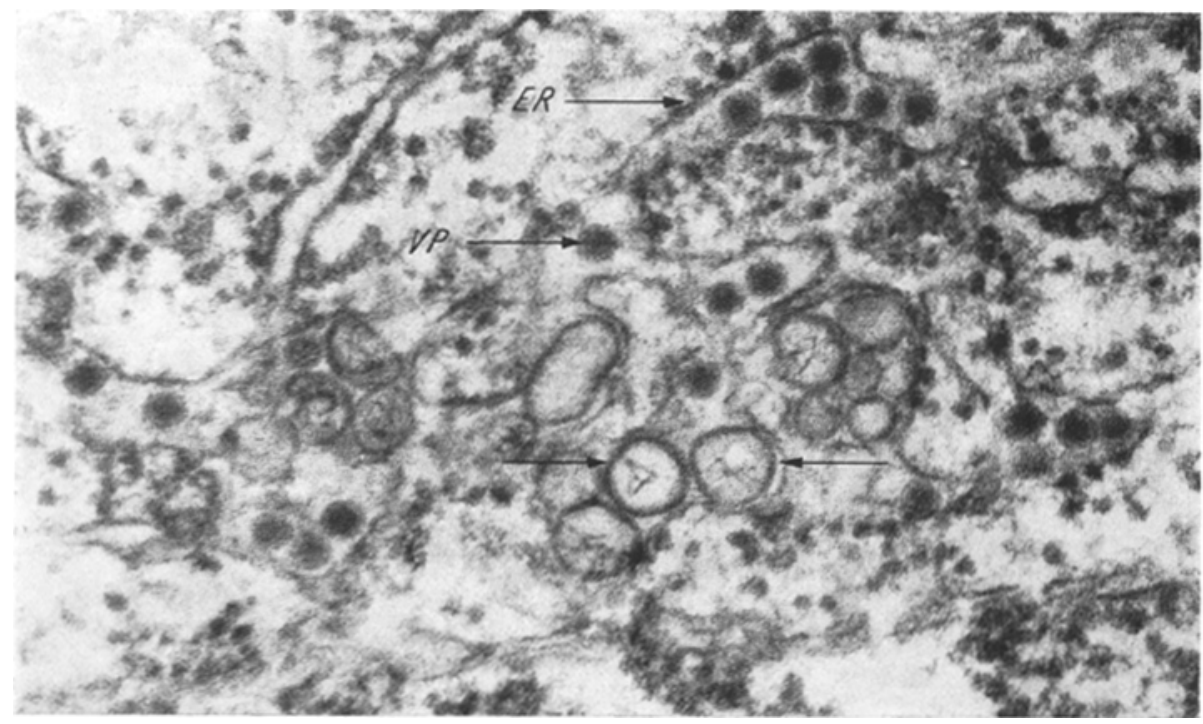

Fig. 8 . Thalamus neurone of 7 -day-old mouse with Zika infection. Fndoplesmic reticulum (ER) contains mature virus particles (VP). Vesicles (arrows) seen in association with endoplasmic reticulum $\times 105,000$

\subsection{Confirmation of Identity}

The $10 \%$ mouse brain pool of Zika virus titred $10^{5} \mathrm{TCD}_{\overline{5} 0}$ per $0.1 \mathrm{ml}$ in monolayers of secondary RMK cells. $100 \mathrm{TCD}_{\tilde{5} 0}$ of this virus was neutralized by the reference antiserum to a dilution of $1: 320$. 


\section{Discussion}

Zika virus appears to have an early effect upon astroglial cells producing enlargement and extension of their processes. Microglial cells do not appear to be excited. In addition the virus affects the pyriform cells of Ammon's horn in a patchy manner. There is no especial predilection for lesions in the periventricular areas (as in neuro-influenzal lesions [6]). Arboviruses in general have been claimed to stimulate astroglia electively (7) but this may be because (in the mouse) this element of the glia is more reactive and certainly more readily stainable than microglia (6). Moreover the same precocious change in astroglia has been found in measles encephalitis in the mouse (BeLr, NARAvg and Freld - unpublished) where microglia remained unaffected.

In the electron microscope Zika virus was found to replicate both in astroglial cells and in neurones. Microglial cells were not encountered with any greater frequency than normal. Replication in neurones indicates that their destruction, so clearly seen in the light microscope, is due specifically to the Zika virus infection. However, in most eases the infected neurons do not show gross damage especially in areas of the cytoplasm remote from the "virus factories". It, therefore, appears possible that the actual cell destruction is due, in part at least, to an immunological elimination mechanism as proposed by RooK and WEBB (8) for Langat virus encephalitis.

The "virus factories" appear to be very similar to cytoplasmic inclusions observed in mouse brains infected with Japanese B encephalitis (JBE) virus (9, 10), central European encephalitis (CEE) virus (11) and Entebbe bat salivary gland (EBSG) virus (12). These are all group B arboviruses and represent members transmitted by mosquitoes (JBE and Zika), by ticks (CEE) and by the bite of the infected host (EBSG) (13). YASUZuMI and his colleagues (9) observed $20 \mathrm{~m} \mu$ particles in the nucleus and suggested that the complete virus was formed in the nucleus, although some precursors were formed in the cytoplasm. The intranuclear particles have not been observed in the other preparations although the cytoplasmic inclusions are normally found in close proximity to the nucleus. Mitochondria are also prevalent in the cytoplasm adjacent to the inclusion. It, therefore, appears that these "virus factories" are indeed the sites of viral replication, although precursors (possibly the ribonucleoprotein) may be formed within the nucleus. Throughout the factories mature virions can be seen within sacs or tubules formed from expanded endoplasmic reticulum and it is believed that this is the actual site of formation of new virus particles. The mode of release of the virus particles from the cell has not yet been demonstrated in vivo.

Tissue cultures infected with three group $B$ arboviruses have been examined in the electron microscope. Murray Valley encephalitis (MVE) virus grown in mosquito cell cultures produces virus factories similar to those described here (14). JBE virus however, replicates in the endoplasmic reticulum of these cells without the formation of a definite inclusion body (14), while in porcine kidney cells JBE virus appears to form by budding from the surface of cytoplasmic vacuoles (15). Finally, Wesselsbron virus produces crystalline and "honey-comb" pattern inclusion bodies in foetal lamb kidney cells with mature particles present in endoplasmic cisternae (16). In the tissue cultures large numbers of mature virus 
particles are present outside the cells and release appears to be by the migration of virion containing vacuoles to the cell membrane (15).

From these observations it is clear that although examination of the growth of arboviruses in tissue cultures is useful, it is necessary to use the intact animal to obtain a picture of the natural pattern of events.

\section{Acknowledgements}

We wish to thank Dr. G. W. Kafuko, Director, East African Virus Researeh Institute, Entebbe, Uganda, for supplying the Zika virus and antiserum.

The authors would also like to thank Miss Greta Joyce, A.I.M.I.T. and Miss Joyce Davison, for histological preparations and for help with electron microseopy respectively.

\section{References}

1. Drok, G. W. A., S. F. Kitchen, and A. J. HADDow : Zika Virus. (1) Isolations and serological specificity. Trans. roy. Soc. trop. Med. Hyg. 46, 509-520 (1952).

2. Weinbren, M. P., and M. C. Williams: Zika Virus: Further isolations in the Zika area, and some studies on the strains isolated. Trans. roy. Soc. trop. Med. Hyg. 52, 263-268 (1964).

3. WoOdall, J. P.: The viruses isolated from arthropods at the East African Virus Research Institute in the 26 years ending December 1963. Proc. E. Afr. Acad. 2, $141-146$ (1964).

4. Haddow, A. J., M. C. Williams, J. P. Woodall, D. I. H. Simpson, and L. K. H. Goma: Twelve isolations of Zika virus from Aedes (Stegomyia) africanus (Theobald) taken in and above a Uganda forest. Bull. Wld Hlth Org. 31, 57-69 (1964).

5. Diск, G. W. A.: Zika virus .(II). Pathogenicity and physical properties. Trans. roy. Soc. trop. Med. Hyg. 46, $521-534$ (1952).

6. BeLt, T. M., H. K. NARANG, and E. J. Freld: Influenzal encephalitis in mice: A histopathological and electron microscopical study. Arch. ges. Virusforsch. 34, $158-167$ (1971)

7. ZLotnIK, I.: The reaction of astrocytes to acute virus infections of the central nervous system. Brit. J. exp. Path. 49, 555-564 (1969).

8. Rook, G. A. W., and H. E. WEBB : Antilymphocyte serum and tissue culture used to investigate role of cell-mediated response in viral encephalitis in mice. Brit. med. J. 4, 210-212 (1970).

9. Yasuzumi, G., I. Tsubo, R. Sugihasa, and Y. Nakar : Analysis of the development of Japanese B encephalitis (JBE) virus. I. Electron microscopic studies of microglia infected with JBE virus. J. Ultrastruct. Res. 11, $213-229$ (1964).

10. Oranagi, S., F. InUta, and E. R. Ross: Electron microscopic observations in mice infected with Japanese encephalitis. Acta neuropath. (Berl.) 13, 169-181 (1964).

11. Blinzinger, K., und W. Mulder: Elektronenmikroskopische Beobachtung des Virus der Frübsommer-Meningo-encephalitis (Stamm HYPR) in Nervenzellen von experimentell infizierten Albinomäusen. Dtsch. Z. Nervenheilk. 197, 18-27 (1970).

12. Peat, A., and T. M. Bell: Entebbe bat salivary gland virus: Electron microscopic study of morphology and development in newborn mice. Arch. ges. Virusforsch. 31, $230-236$ (1970).

13. Williams, M. C., D. I. H. Simpson, R. C. Shepherd, J. P. O'Sullivan, J. C. Cunningham, and M. Lule: Virus isolation from bats. Rep. F. Afr. Virus Res. Inst. 14, $42(1.965)$. 
14. Filshie, B. K., and J. RehaceK: Studies on the morphology of Murray Valley encephalitis and Japanese encephalitis growing in cultured mosquito cells. Virology $34,435-443(1968)$.

15. OTA, Z. Electron microscopic study of the development of Japanese B encephalitis virus in porcine kidney stable (PS) cells. Virology 25, 372-378 (1965).

16. Paricer, J. R., and L. M. Stannard: Intracytoplasmic inclusions in foetal lamb kidney cells infected with Wesselsbron virus. Arch. ges. Virusforsch. 20, 469-472 (1967).

Authors' address: Dr. T. M. BeLL, Medical Research Council, Demyelinating Diseases Unit, Newcastle General Hospital, Westgate Road, Newcastle upon Tyne, NE 46 BE, England. 